\title{
A small cell bronchogenic carcinoma associated with tumoral hypophosphataemia and inappropriate antidiuresis
}

\author{
N. Robin, G. Gill, C. van Heyningen ${ }^{1}$ and W. Fraser ${ }^{2}$ \\ Departments of Medicine and ${ }^{1}$ Chemical Pathology, Walton Hospital, Liverpool L9 1 AE and ${ }^{2}$ University \\ Department of Clinical Chemistry, Royal Liverpool University Hospital, Liverpool, UK
}

\begin{abstract}
Summary: A patient is described with small cell carcinoma of the lung, associated with profound hypophosphataemia and hyponatraemia. Increased phosphate excretion and inappropriately high urine osmolality were observed. The abnormalities are consistent with tumoral hypophosphataemia and inappropriate antidiuresis. These tumour-related metabolic abnormalities have only been described once before with this malignancy.
\end{abstract}

\section{Introduction}

Significant and prolonged hypophosphataemia is an unusual metabolic disturbance. Causes include hyperglycaemic diabetic emergencies, hyperparathyroidism, renal tubular acidosis, malabsorption and malnutrition. ${ }^{1.2}$ Hypophosphataemia may also be rarely associated with certain tumours, ${ }^{3}$ possibly due to the autonomous secretion of parathyroid hormone-related protein (PTHrP) inhibiting tubular resorption of urinary phosphate, which may in turn lead to 'phosphaturic osteomalacia' if hypophosphataemia is prolonged. 'Tumoral hypophosphataemia' may be associated with a variety of neoplasms. ${ }^{3-8}$ It is always rare and is especially so if associated with other syndromes of tumoral hormone production. We report here an unusual case of small cell carcinoma of the lung, associated with tumoral hypophosphataemia and also the syndrome of inappropriate antidiuresis (SIAD).

\section{Case report}

A 72 year old man was admitted with chest pain and weight loss. He had a past history of myocardial infarction and peptic ulceration. He had smoked 20 cigarettes a day for many years but drank little alcohol. Examination revealed finger clubbing but no other significant clinical abnormalities. Chest X-ray and computed tomography (CT) showed a right hilar tumour with mediastinal lymph node involvement. Bronchoscopic biopsy revealed a small cell carcinoma.

Correspondence: G. Gill, M.D., M.Sc., F.R.C.P. Accepted: 7 February 1994
Routine biochemical screening showed consistent severe hypophosphataemia and hyponatraemia (see Table I). Urinary phosphate clearance was increased and tubular reabsorption of phosphate decreased. Serum calcium was consistently? normal but alkaline phosphatase was moderately raised. Isoenzyme electrophoresis demonstrated the alkaline phosphatase to be of bone and live? origin. Pelvic X-rays were normal. Serum bilirubin and alanine aminotransferase (ALT) levels were normal. Levels of aspartate aminotransferase (AST) and gamma-glutamyl aminotransferase (GGT) were slightly elevated, but liver ultrasound scan was normal. Haemoglobin level, blood glucose, plasma proteins, urea and creatinine were within laboratory reference ranges. Urine analysis by semi-quantitative dipstick showed no excess of glucose or protein. Arterial blood gas concentrations and $\mathrm{pH}$ were also normal.

Details of hyponatraemia are also given in Table I. At the time of osmolality studies, serum sodium was $117 \mathrm{mmol} / 1$ and serum osmolality similarly low at $249 \mathrm{mosmol} / \mathrm{kg}$. Urine osmolality was inappropriately raised at $375 \mathrm{mosmol} / \mathrm{kg}$. Renal function as assessed by serum creatinine was consistently normal, the patient was not on diuretic drugs and was clinically euvolaemic. Adrenal function was normal by Synacthen testing.

Before further investigation or treatment could be planned, the patient deteriorated rapidly and died. Permission for autopsy was refused.

\section{Discussion}

Tumoral hypophosphataemia, sometimes also known as 'tumorous phosphaturic osteomalacia', 
Table I Biochemical findings in a patient with tumour-associated hypophosphataemia and SIAD

\begin{tabular}{|c|c|c|}
\hline & & Reference range \\
\hline \multicolumn{3}{|l|}{ (A) Mineral metabolism } \\
\hline Serum phosphate & $\begin{array}{l}0.27 \mathrm{mmol} / 1 \\
(0.22-0.40)\end{array}$ & $0.70-1.60$ \\
\hline Phosphate clearance & $23 \mathrm{ml} /$ minute & $5-15$ \\
\hline $\begin{array}{l}\text { Tubular reabsorption } \\
\text { of phosphate }\end{array}$ & $\begin{array}{l}64 \% \\
\text { (when serum phosphatase } 0.27 \\
\mathrm{mmol} / 1 \text { and serum creatinine } \\
64 \mu \mathrm{mol} / \mathrm{l} \text { ) }\end{array}$ & $80-90 \%$ \\
\hline $\begin{array}{l}\text { PTH-related peptide } \\
\text { (PTHrP) }\end{array}$ & $<0.9 \mathrm{pmol} / \mathrm{l}$ & $0.7-2.6$ \\
\hline PTH & $4.5 \mathrm{pmol} / 1$ & $1.1-6.9$ \\
\hline $1,25 \mathrm{diOH}$ vit $\mathrm{D}$ & $11.6 \mathrm{pg} / \mathrm{ml}$ & $18-62$ \\
\hline $24 \mathrm{OH}$ vit $\mathrm{D}_{3}$ & $<6 \mathrm{ng} / \mathrm{ml}$ & $5-25 \mathrm{ng} \mathrm{ml}$ (winter) \\
\hline Serum calcium & $2.28 \mathrm{mmol} / \mathrm{l}$ & $2.22-2.70$ \\
\hline Serum alkaline phosphatase & $\begin{array}{l}216 \mathrm{U} / 1 \\
\text { (isoenzymes bone and } \\
\text { liver mixed) }\end{array}$ & $30-130$ \\
\hline Serum albumin & $43 \mathrm{~g} / \mathrm{l}$ & $35-45$ \\
\hline \multicolumn{3}{|c|}{ (B) Water and electrolyte metabolism } \\
\hline Serum sodium & $117 \mathrm{mmol} / \mathrm{l}$ & $135-145$ \\
\hline Serum potassium & $3.9 \mathrm{mmol} / 1$ & $3.5-5.0$ \\
\hline Serum chloride & $84 \mathrm{mmol} / \mathrm{l}$ & $95-105$ \\
\hline Serum bicarbonate & $22 \mathrm{mmol} / \mathrm{l}$ & $20-28$ \\
\hline
\end{tabular}

1,25 diOH vit $D=1,25$ dihydroxy vitamin $D ; 25 \mathrm{OH}$ vit $D_{3}=25$ hydroxy vitamin $D_{3}$.

is a well-recognized but rare syndrome $e^{1,2}$ characterized by hypophosphataemia, normocalcaemia, hyperphosphaturia, elevated serum alkaline phosphatase and often clinical features of osteomalacia (bone pain, muscular weakness, X-ray changes, etc.). Most cases reported have been associated with benign mesenchymal tumours, ${ }^{3,4}$ although malignant neoplasms also have occasionally been involved. ${ }^{5}$ Of these, only three non-mesenchymal malignancies have been reported - two carcinomas of prostate ${ }^{6}$ and one of lung. ${ }^{7}$

Our patient had a histologically proven small cell carcinoma of the lung with good biochemical evidence of tumoral hypophosphataemia. Low serum levels of 1,25 dihydroxy vitamin $D$ are well known to be low in this syndrome, probably due to inhibition of hydroxylation. ${ }^{2}$ Serum 25 hydroxy vitamin D levels are usually normal. ${ }^{5}$ Our patient's low level may have been because he presented in the middle of winter. He had no clinical or radiological features of overt osteomalacia, presumably because of his short-duration history. There were no overt features of poor nutrition, and haemoglobin and serum albumin were quite normal. Serum calcium and PTH levels were also unremarkable. There was also no evidence of renal tubular acidosis (or other tubular dysfunction) as a cause for the patient's hypophosphataemia. Arterial $\mathrm{pH}$ was normal, serum chloride was not elevated and serum bicarbonate, urea and creatinine were normal.

Hyponatraemia was also present, associated with serum hypo-osmolality, relative urine hyperosmolality, normal renal and adrenal function, and absence of hypovolaemia or diuretic treatment. This fulfils the classical criteria of Bartter and Schwar $z^{8}$ for the diagnosis of associated inappropriate antidiuresis (SIAD) and this case represents only the second reported case of small cell carcinoma of lung with the combined metabolic abnormalities of SIAD and tumoral hypophosphataemia. $^{7}$

The putative humoral mediator of tumoral hypophosphataemia is uncertain. It certainly inhibits renal tubular resorption of phosphate, and appears to interfere with vitamin $D$ hydroxylation. ${ }^{9}$ This combined abnormality is similar to that found in X-linked hypophosphataemic rickets. ${ }^{10}$ PTHrP is a possible mediator of the tumoral hypophosphataemic syndrome. ${ }^{11}$ As in our case, however, levels are not always raised, and it is possible that there are other as yet undetectable PTH-like peptides, which may lead to hypophosphataemia. In this context, it is of considerable interest that a recent report ${ }^{12}$ appears to identify a humoral factor which inhibits renal tubular reabsorption of phosphate, and which is distinct from PTHrP, as a mediator of oncogenic osteomalacia. 


\section{References}

1. Paterson, C.R., Naismith, K.I. \& Young, J.A. Severe unexplained hypophosphataemia. Clin Chem 1992, 38: 104-107.

2. Hewison, M., Karmali, R. \& O'Riordan, J.L.H. Tumor induced osteomalacia. Clin Endocrinol 1992, 37: 382-384.

3. Ryan, E.A. \& Reiss, E. Oncogenous osteomalacia. Review of the world literature of 42 cases and report of 2 new cases. $\mathrm{Am}$ $J$ Med 1984, 77: 501-512.

4. Daniels, R.A. \& Weisenfeld, I. Tumorous phosphaturic osteomalacia. Report of a case associated with multiple haemangiomas of bone. Am J Med 1979, 67: 155-159.

5. Harvey, J.N., Gray, C. \& Belchetz, P.E. Oncogenous osteomalacia and malignancy. Clin Endocrinol 1992, 37: 379-384.

6. Lyles, K.W., Berry, W.R., Haussler, M., Harrelson, J.M. \& Drezner, M.K. Hypophosphataemic osteomalacia: association with prostatic carcinoma. Ann Intern Med 1980, 93: 275-278.

7. Taylor, H.C., Fallan, M.D. \& Velasco, M.E. Oncogenic osteomalacia and inappropriate antidiuretic hormone secretion due to oat cell carcinoma. Ann Intern Med 1984, 101: 786-788.

8. Bartter, F.C. \& Schwartz, W.B. The syndrome of inappropriate secretion of antidiuretic hormone. Am J Med 1967, 42: 790-806.

9. Sweet, R.A., Males, J.L., Hamstra, A.J. \& DeLuca, H.F. Vitamin D metabolite levels in oncogenic osteomalacia. Ann Intern Med 1980, 93: 279-280.

10. Rasmussen, H., Pechet, M., Anast, C., Mazur, A., Gertner, J. \& Broadus, A.E. Long-term treatment of familial hypophosphataemic rickets with oral phosphate and $1 \alpha$ hydroxyvitamin $\mathrm{D}_{3}$. J Paediat 1981, 99: 16-25.

11. Seshadri, M.S., Mason, C.R.S. \& Posen, S. Parathyroid hormone-like bioactivity in tumours from patients with oncogenic osteomalacia. Clin Endocrinol 1985, 23: 689-697.

12. Cai, Q., Hodgson, S.F., Kao, P.C., Lennon, V.A., Klee, G.G., Zinsmiester, A.R. \& Kumar, R. Brief report: inhibition of renal phoshate transport by a tumor product in a patient with oncogenic osteomalacia. $N$ Engl $J$ Med 1994, 330: $1645-1649$. 